KALAM, P-ISSN: 0853-9510, E-ISSN: 2540-7759

http://ejournal.radenintan.ac.id/index.php/kalam

DOI: http://dx.doi.org/10.24042/klm.v13i2.3529

Volume 13, Number 2, December 2019, p. 191-216

\title{
Implementation of Pluralism Values in Indonesia and Its Relevance to The Medina Charter
}

\author{
Abdul Malik Ghozali \\ Universitas Islam Negeri Raden Intan Lampung \\ abdul.malik@radenintan.ac.id
}

\begin{abstract}
Ahmad Zaeny
Universitas Islam Negeri Raden Intan Lampung

ahmadzaeny@radenintan.ac.id
\end{abstract}

\begin{abstract}
Violence due to religious conflict is still becoming one of the problems faced by almost all countries, including Indonesia. Religious doctrine is often understood so narrowly that it imprisons its adherents in religious exclusivism and triggers conflict. In the context of a pluralistic Indonesian society, anticipatory efforts need to be made so that violence in the name of religion can be avoided. One of the efforts is by strengthening the values of pluralism. This article examines the implementation of the values of pluralism among the people of the village of Hanura Pesawaran Lampung while looking for its relevance to the values of pluralism that exist in the Medina Charter. This study is a field research using a qualitative approach. This study is field research using a qualitative approach. Data were obtained by observing, documenting, and interviewing community leaders in the village of Hanura. The results showed that the people of Hanura village had implemented pluralism values well. This can be seen from three indicators, namely: recognition of equal rights and obligations, the existence of social coherence, and community tolerance. These three things are following the values of pluralism in the Medina Charter. In conclusion, the life of Hanura villagers can be used as a model of the implementation of the values of pluralism in society.
\end{abstract}

Keywords : Pluralism, Madina Charter, Equality of Right, Coherence of Social Activities, Religious Tolerance. 
Abstrak : Kekerasan akibat konflik agama masih menjadi salah satu persoalan yang dihadapi hampir semua negara, termasuk Indonesia. Doktrin agama seringkali dipahami secara sempit sehingga memenjarakan penganutnya dalam eksklusivisme agama dan menjadi pemicu terjadinya konflik. Dalam konteks masyarakat Indonesia yang majemuk, upaya antisipasi perlu dilakukan agar peristiwa kekerasan atas nama agama dapat dihindari. Salah satu upayanya adalah dengan melakukan penguatan terhadap nilai-nilai pluralisme. Artikel ini mengkaji implementasi nilainilai pluralisme di kalangan masyarakat desa Hanura Pesawaran Lampung sambil mencari relevansinya dengan nilai-nilai pluralisme yang ada dalam Piagam Madinah. Kajian ini merupakan penelitian lapangan dengan menggunakan pendekatan kualitatif. Data diperoleh dengan melakukan observasi, dokumentasi, dan wawancara terhadap tokoh masyarakat di desa Hanura. Hasil penelitian menunjukkan bahwa masyarakat desa Hanura telah mengimplemen-tasikan nilai-nilai pluralism dengan baik. Hal itu bisa dilihat dari tiga indikator, yaitu: pengakuan adanya persamaan hak dan kewajiban, adanya koherensi kegiatan sosial, dan toleransi masyarakat. Tiga hal itu sesuai dengan nilai-nilai pluralisme yang ada dalam Piagam Madinah. Artikel ini menyimpulkan bahwa kehidupan masyarakat desa Hanura dapat dijadikan sebagai satu model penerapan nilai-nilai pluralisme dalam masyarakat

Kata Kunci : Pluralisme, Piagam Madina, Persamaan Hak, Koherensi Aktifitas Sosial, Toleransi Beragama.

\section{A. Introduction}

Violence due to religious conflict is one of the problems faced by almost all countries, including Indonesia. Religious doctrine is often used as an excuse to trigger conflicts in society. It happens because religion is understood so narrowly that it becomes a source of community conflict. Thus, religion, which actually should bring harmony and community peace, turns into a threat and triggers disputes between followers of the religion. The number of bloody events shows how religion is used as a trigger for nonviolence. Conflicts between Muslims and Christians in the case of the Crusades, the massacre of the Rohingya Muslims, the massacre of Muslims in New Zeland, ISIS, including, in the context of Indonesia, riots in Ambon, Sampit, Balinuraga and several other places, are clear examples of how religion was made as a trigger source of conflict between religious communities. As a country whose people are made up of plural society, Indonesia needs to make anticipatory efforts so that violence in the name of 
religion can be avoided and will not be repeated in the future. One of the efforts is to strengthen the values of pluralism.

From the beginning, the Indonesian people have been aware and recognized the diversity of ethnicity and religion among the people. This awareness and recognition are manifested in a national motto, Bhinneka Tunggal Ika (unity in diversity). With this awareness, harmony is created in the midst of society. In many ways, harmony can not be separated from the influence of the teachings of Islam as the religion of majority of Indonesians. Islam that developed in Indonesia has a different character from Islam in its original place. Azyumardi Azra calls Indonesian Islam "Islam with a smiling face", a peaceful and moderate Islam. ${ }^{1}$ While Syafi'i Maarif calls Islam in Indonesia a special form of Islam within the Indonesian frame. ${ }^{2}$

The concept of pluralism, popularized by Frithjof Schuon ${ }^{3}$ and John $\mathrm{Hick}^{4}$, is aimed at developing tolerance and maintaining harmony in life between religious communities amid diversity. ${ }^{5}$ Thus, it is hoped that no more religion claims to be the owner of absolute truth because religion is seen as the result of various feelings and experiences of human diversity, in other words all religions contain Divine truth. ${ }^{6}$ From here, then, religious pluralism is considered as the right solution to prevent conflict and create harmony in the world's religious community. Tolerance is manifested by acknowledging the existence of each religion and not assuming that only its religion is the most correct. ${ }^{7}$

Until now, the existence of pluralism still leaves suspicion from the clergy because it brings the relativity of truth to every religion in the world. One form of suspicion of the concept of pluralism was conveyed by Ps. Stervi

${ }^{1}$ Azyumardi Azra, "Bali and Southeast Asia Islam: Debunking The Mith," in Kumar Ramakishna dan See Seng Tan.eds., After Bali: The Threat of Terrorism in Southeast Asia, (Singappre: World Scientific Publishing Co. Pte. Ltd., 2003): 45.

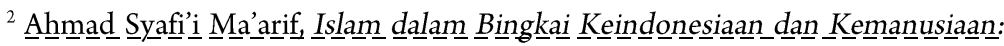

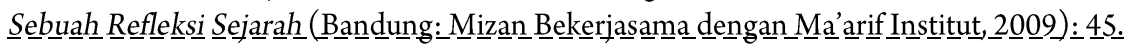

${ }^{3}$ See Frithjof Schuon, The Transcendent Unity of Religions (n.p.: Quest Book Theosophical Publishing House, 1984).

4 See John Hick, Tuhan Punya Banyak Nama, trans. Amin Ma'ruf, Cet. I (Yogyakarta: Interfidei, 2006).

${ }^{5}$ M. Legenhausen, Pluralitas Dan Pluralisme Agama (Jakarta: Shadra Press, 2010): 37 .

${ }^{6}$ Ibid., : 19 .

${ }^{7}$ Ibid., : 37-38. 
Indra Lumintang who stated that pluralism is a challenge as well as a very serious danger for Christianity. ${ }^{8}$ The same thing was conveyed by Anis Malik Thoha saying that pluralism is a "new religion". Therefore this concept is very dangerous and needs to get extra attention and vigilance from all adherents of each religion in the world. ${ }^{9}$

On the other hand, there are not a few intellectuals and religious figures who voiced the need to revive pluralism in every element of society. In Indonesia, several central figures who support this understanding of religious pluralism include Mukti Ali, Nurkholis Madjid, and Abdurrahman Wahid. Mukti Ali proposed the concept of "agreeing in disagreement. Nurkholis Madjid who launched the idea of secularism and inclusivepluralist theological ideas with the QS menu. Al-Baqarah: 148 as the basis for understanding pluralism. ${ }^{10} \mathrm{He}$ explained that "Indonesia is one of the most pluralist nations in the world". ${ }^{11}$ The same thing was also conveyed by Abdurrahman Wahid who asserted that pluralism in Indonesia is the interpretation of the teachings of Islam as Rahmatan lil Alamin. Islam is a religion that teaches affection to its adherents. Islam strongly opposes violence and discrimination against fellow human beings. Abdurrahman Wahid asserted that "pluralism is a fixed price". Pluralism is an absolute solution to develop Indonesia which consists of many ethnic groups and religions. Pluralism is the best way to behave and act. In short, pluralism must be a way of looking at building a better future for Indonesia. ${ }^{12}$

Studies on the values of pluralism have been carried out by academics. among others by Budi Munawar-Rachman, ${ }^{13} \mathrm{Ummi}$ Sumbulah

${ }^{8}$ Stevri Indra Lumintang, Teologi $\mathrm{Abu}-\mathrm{Abu}$ (Pluralisme Iman), Cet. I (Malang: YPPII, 2002): 15.

${ }_{9}$ Anis Malik Thoha, "Konsep World Theology Dan Global Theology Eksposisi Doktrin Pluralisme Agama, Smit Dan Hick," ISLAMIA Vol. 1, no. 4 (2005): 59.

${ }^{10}$ Nurcholish Madjid, Kebebasan Beragama Dan Pluralisme Dalam Islam (Jakarta: Gramedia Pustaka Utama, 2001): 173.

${ }^{11}$ Nurcholish Madjid, Masyarakat Religius (Jakarta: Paramadina, 2000): 35-39.

${ }^{12}$ Rumadi, Damai Bersama Gus Dur (Jakarta: Kompas Media Nusantara, 2010), p.16.; Baca juga Abdurrahman Wahid, Prisma Pemikiran Gus Dur (Yogyakarta: LKiS, 2010).

13 Budi Munawar-Rachman, "Perspektif Global Islam Dan Pluralisme," Ilmu Ushuluddin Volume 1, no. 3 (2012). 
and Nurjannah, ${ }^{14}$ Faiq Nebukadnezar, ${ }^{15}$ Harda Armayanto, ${ }^{16}$ M. Syaiful Rahman, ${ }^{17}$ Catur Widiatmoko, ${ }^{18}$ Umi Hanik, ${ }^{19}$ Ahmad Khaerurrozikin, ${ }^{20}$ Achmad $^{21}$, and others. However, none of them has studied the implementation of pluralism in Indonesia and sought its relevance to the values in the Medina Charter. To fill this gap, this article tries to examine the implementation of the values of pluralism in the Hanura village community as well as to find its relevance to the values of pluralism that exist in the Medina Charter. This study is a field research with a qualitative approach. Data obtained by observing, documenting, and interviewing community leaders in the village of Hanura.

\section{B. Religious Pluralism}

The term "pluralism" comes from the word plural which means more than one. ${ }^{22}$ In The Oxford English Dictionary it is stated that pluralism is understood as: (1) A theory that opposes the power of a monolithic state, and vice versa, supports decentralization and autonomy for the main organizations representing individual involvement in society. It is also a belief that power must be shared among a number of political parties. (2) The existence or tolerance of ethnic diversity or cultural groups in a society or country, as well as the diversity of beliefs or attitudes within a body,

${ }^{14}$ Umi Sumbulah and Nurjannah, Pluralisme Agama: Makna Dan Lokalitas Pola Kerukunan Antarumat Beragama (Malang: UIN-Maliki Press, 2013).

15 Faiq Nebukadnezar, "Pandangan Al-Qur'an Terhadap Pluralisme Agama: Telaah Kritis Ayat-Ayat Teologis Dalam Al-Qur'an'” (Tesis, Surakarta, IAIN Surakarta, 2018). (2014).

${ }^{16}$ Harda Armayanto, "Problem Pluralisme Agama," Jurnal Tsaqafah Vol. 10, no. 2

${ }^{17}$ M. Syaiful Rahman, “Islam Dan Pluralisme," Fikrah Vol. 2, no. 1 (n.d.): 2014.

${ }^{18}$ Catur Widiat Moko, "Pluralisme Agama Menurut Nurcholis Madjid (19392005) Dalam Konteks Keindonesiaan,” Medina-Te Vol. 16, no. 1 (2017).

19 Umi Hanik, "Pluralisme Agama Di Indonesia," Tribakti: Jurnal Pemikiran Keislaman Vol. 25, no. 1 (2014).

${ }^{20}$ Ahmad Khaerurrozikin, "Problem Sosiologis Pluralisme Agama Di Indonesia," Jurnal Kalimah Vol. 13, no. 1 (2015).

${ }^{21}$ Achmad, "Pluralisme Dalam Problema," Jurnal Sosial Humaniora Vol. 7, no. 2 (2014).

${ }^{22}$ A.S.S. Hornby,_Oxford XI (London: Oxxford Univer 
institution, and so on. ${ }^{23}$ The first definition contains the notion of political pluralism, while the second definition contains the notion of social or primordial pluralism.

In the Dictionary of Philosophy, Pluralism is characterized by the existence of certain beliefs in the form of: (1) Fundamental reality is plural; It is different from dualism - which states that there are two fundamental realities - and monism - which states that there is only one fundamental reality. (2) There are many levels of things in a separate universe, which cannot be redirected, and are themselves independent. (3) The universe is basically not determined in any form; lacks fundamental harmony or unity, there is no fundamental coherent and rational order. ${ }^{24}$ But in The Encyclopedia of Religion, it is mentioned that the term pluralism refers to the fact that the history of religions shows the plurality of traditions and the plurality of groups in each religion. Philosophically, pluralism is a theory about the relationship between these traditions with differences and claims of each competition. ${ }^{25}$

From these definitions, the word pluralism can be simplified into two senses: first, the recognition of diversity of groups - whether racial, religious, ethnic, sectarian, or party - by continuing to uphold aspects of differences that are very typical between groups - that group. Second, the doctrine which views that there are no right opinions or all opinions are equally true. ${ }^{26}$ From the first understanding pluralism can be interpreted as tolerance, while the second understanding implies the relativity of truth which views that there is no truth or all are equally true. ${ }^{27}$

The term "religious pluralism" is a term that refers to an understanding or perspective on religious plurality. This understanding views all religions as equal or equal to other religions. ${ }^{28}$ As John Hick's

${ }^{23}$ See "Oxford Advanced Learner's Dictionary" (London: Oxford University Press, 1989): 953.

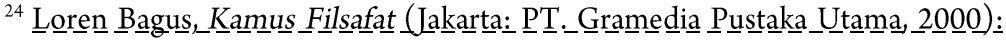
$\underline{8} 53$.

25 The Encyclopedia of Religion (New York: Simon \& Schuster Macmillan, 1995): 331 .

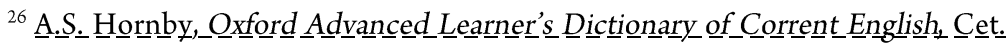

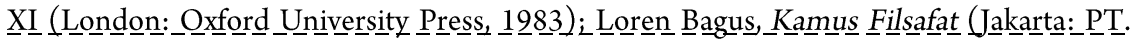

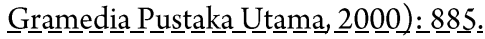

${ }^{27}$ Khaerurrozikin, "Problem Sosiologis Pluralisme Agama Di Indonesia."

${ }^{28}$ Adian Husaini, Wajah Peradaban Barat (Jakarta: Gema Insani, 2005): 339. 
understanding, religious pluralism is the idea that the world's major religions are different perceptions and conceptions of the Real or the Most Great from a variety of human cultures; and that the transformation of the human form from self-centering to essential-centering takes place in real terms in human culture - and occurs, as far as one can be observed, to the same extent. ${ }^{29}$ The understanding given by Hick shows that true religion is "manifestations of one reality".

A similar understanding was conveyed by Nurcholish Madjid when explaining pluralist attitudes. According to Majid, the pluralist attitude can be expressed in several formulations, for example: "Other religions are equally legitimate ways of achieving the same Truth," Other religions speak differently, but are truths that are equally valid", or "Every religion expresses an important part of truth ". ${ }^{30}$ From this definition it can be understood that there is a similarity in the "truth" of every religion, or all religions are equally true. This similarity becomes the basis for any religion to claim that their religion is also true and safe, and that salvation on the Hereafter will be achieved by all religious groups. ${ }^{31}$

Zuhairi Misrawi gives a somewhat different definition. According to his understanding, pluralism does not teach all religions alike. On the contrary, pluralism teaches that religion is inherently different. The existence of these differences makes pluralism find relevance to reconcile and build tolerance. He also asserts that pluralism actually speaks at the level of facts and reality, not at the theological level. At the theological level it must be believed that each religion has its own ritual, whereas on a social level, active involvement between all walks of life is needed to build togetherness. ${ }^{32}$ In line with this understanding, Anis Malik Thoha defines religious pluralism as a condition of shared life (coexistence) between religions (in a broad sense) that varies in one community, while maintaining the specific characteristics or teachings of each religion. ${ }^{33}$ From the definitions above it

${ }^{29}$ John Hick, An Interpretation of Religion: Human Respons to the Transcendent (London: Macmillan, 1989): 36.

${ }^{30}$ Nurcholish Madjid, Tiga Agama Satu Tuhan (Bandung: Mizan, 1999).

31 Jalaluddin Rakhmat, Islam Dan Pluralisme: Akhlak Qur'an Menyikapi Perbedaan, Cet. II (Jakarta: Serambi, 2006): 23.

${ }^{32}$ Ibid.: 205-207.

${ }^{33}$ Anis Malik Thoha, Tren Pluralisme Agama, Cet. I (Jakarta: Perspektif, 2005): 14. 
can be understood that there are actually differences and dissimilar views among academics about the concept of pluralism.

An interesting thing to study is that the bearers of pluralism in the Muslim world actually base their theoretical arguments with Islamic religious texts. Some verses that are used as references for their arguments include QS. Al-Ankabuut [29]: 46, QS. Al-Maidah [5]: 48, QS. Al-Baqarah [2]: 285, and others. Even historically, the recognition of religious pluralism was demonstrated by the Prophet when he became a religious leader as well as a political leader in Medina. At that time, Jewish groups, Christians and paganist groups, were not forced to convert to Islam. They get the same treatment, with the same rights and obligations as other citizens. Recognition of pluralism during the time of the Holy Prophet. it is documented in an agreement called the Medina Charter.

Totally, the Medina Charter consists of 47 considerations reflecting 5 basic principles. First, the principle of shura (deliberation). Second, the principle of justice. Third, the principle of freedom. Fourth, the principle of equality. Fifth, the principle of obedience. But according to Sukarja, after reviewing article by article in the Medina Charter, he concluded the general principles or points of thought in the charter as follows: (1) Monotheism, this is found in the preamble and chapters $22,23,42$, and the end article 47. (2) Unity and integrity, this is stated in articles: 1, 15, 17, 25 and article 37. (3) Equality and justice, reflected in articles: 13, 15, 16, 22, 23, 24, 37 and article 40. (4) Freedom of religion, illustrated in article 25. (5) Defending the state, contained in articles 24, 37, 38 and article 44. (6) Preservation of good customs, listed in articles 2, 3, 4, 5, 6, 7, 8, 9 and 10. (7) Shari'ah supremacy, listed in article 23 and article 42. (8) Politics of peace and protection, summarized in articles 17, 36, 37, 39, 40, 41 and article 47; while the attitude of peace is externally affirmed in article 45 . The principles contained in the Medina Charter reflect the principles contained in the Koran relating to the fostering of political society. ${ }^{34}$ In fact, in Harun Nasution's view, the principles in the Medina Charter are what Muslims need as a guide in regulating Islamic societies according to the demands of the times. ${ }^{35}$

${ }^{34}$ Ahmad Sukarja, Piagam Madinah \& UUD NKRI 1945 (Jakarta: Sinar Grafika, 2012): 116 .

${ }^{35}$ Harun Nasution, "Islam dan Sistem Pemerintahan Dalam Perkembangan Sejarah,” Nuansa, (Jakarta: Desember 1984): 6. 


\section{Implementation of the Value of Pluralism in Hanura Village}

Hanura Village is a coastal village located in the southern bay of Lampung. In total Hanura village covers +600 hectares with a stretch of coastline along $2 \mathrm{~km}^{36}$ In 2016, Hanura village was selected as a pilot village in Lampung and National provincial level IT services. This is because the village has an official website that contains information about various village activities with the website address: http / www.hanura.desa.id.

The name of the village of Hanura is an abbreviation of "People's Conscience". Historically, this village was a second period of Army transmigration in Lampung, which was initiated by General Ahmad Yani, the then Minister of Army Commander. The village was founded on September 17, 1966 which was later celebrated as the anniversary of the village of Hanura. ${ }^{37}$ At present the population of the village of Hanura is 1,535 families, consisting of 2575 men and 2481 women. The majority of Hanura villagers work as farmers. ${ }^{38}$

In terms of ethnicity and religion of the population, the village of Hanura is a multi-ethnic and multi-religious village. The inhabitants of the village of Hanura consist of several tribes; Javanese, Lampung, Padang etc. While the religious diversity of Hanura villagers is broadly divided into three religious adherents: Islam, Protestantism and Catholicism. In plain view the diversity of religions in the village of Hanura can be seen from the houses of worship that stand side by side namely; Mosque, Protestant Church and Catholic Church.

Despite the fact that the inhabitants of the village of Hanura are quite plural, so far they have lived in harmony and peace. Ethnic and religious differences between the villagers do not cause conflict. It shows that the Hanura village community can be an example for the implementation of pluralism values. This can be seen from at least three parameters: 1) Equal rights and obligations; 2) coherence of community social activities (harmony); and 3) tolerance in religion (inclusive). In accordance with the findings in the field research, these three indicators were implemented in the life of the Hanura villagers.

\footnotetext{
36 "Profil Desa Hanura," Youtube, accessed June 7, 2019, https://www.youtube.com/watch?v=DVgMH0Vk9W4.

${ }^{37}$ Ibid.

38 “Profil Desa Hanura," Situs Web Resmi Desa Hanura, accessed July 19, 2019, http://hanura.desa.id/profil/.
} 


\section{Equal rights and obligations between citizens}

The people of Hanura village uphold the equal rights and obligations of fellow community members. Normatively, the government of Hanura Village has tried to socialize Law No. 6 of 2014 concerning Village regulation which regulates the rights and obligations of village communities. This can be seen on the website of the village of Hanura (http://hanura.desa.id/hak-dan-kewajib-masyarakat-desa/). The norm confirms that the people of Hanura village have the same rights and obligations before the law and village government. So they must be treated equally in the services provided by the village government.

Recognition of equal rights and obligations of citizens in the village of Hanura was also implemented in social and religious life. In a variety of religious social activities, religious adherents do not discriminate against citizens because of differences in belief. This can be seen during the celebration of the Eid al-Adha holiday. Sacrificial meat sacrificed at the time of the feast is distributed to all people in need regardless of their beliefs. The same thing can be done by Christians and Catholics. At certain times they carry out social activities, such as free medical treatment, provision of groceries and others, involving all members of the community regardless of their belief status. According to Pastor Beta Herlin's explanation (Pastor of Beith Tefilah Protestan Church), the involvement of the community members in these social activities is not done to intervene in religious areas, but rather as a form of social care for those in need without distinguishing the religious status held. ${ }^{39}$

The attitude of acknowledging equality among Hanura villagers also appears in matters of worship. As citizens, Hanura villagers recognize the religious freedom of their citizens as regulated in the 1945 Law Article 29 paragraph 2. The form of implementation of the recognition of religious freedom in the village is illustrated in the construction of places of worship as places for carrying out religious rituals of each religion. Researchers found the fact that the jami mosque 'Bait al-Iqrar in the village of Hanura was built in a location almost opposite the Beth Tefilah Protestant Church, which is on the provincial main street jl. Ratay Way. While in other places, not far from the location of the two places of worship, stood the Catholic Church of St. Martin. Until now they are living in harmony and there is no data found

${ }^{39}$ Beta Herlin, Pastor of Beith Tefilah Protestan Church, Interview, 6 September 2018. 
of a conflict between them. This indicates that the Hanura villagers recognize the freedom of each villager to embrace a religion and worship according to their respective religious teachings.

Another interesting fact is the location of the cemetery. In most communities the burial sites are separated based on faith. If a person of a certain religion dies, he will be buried in a special cemetery according to his religion. So it is known that there is a Christian cemetery, Muslim cemetery and so forth. But in the village of Hanura, the community did not discriminate between the burial sites. They buried each of their citizens in the village public cemetery and did not divide it with certain blocks. ${ }^{40}$

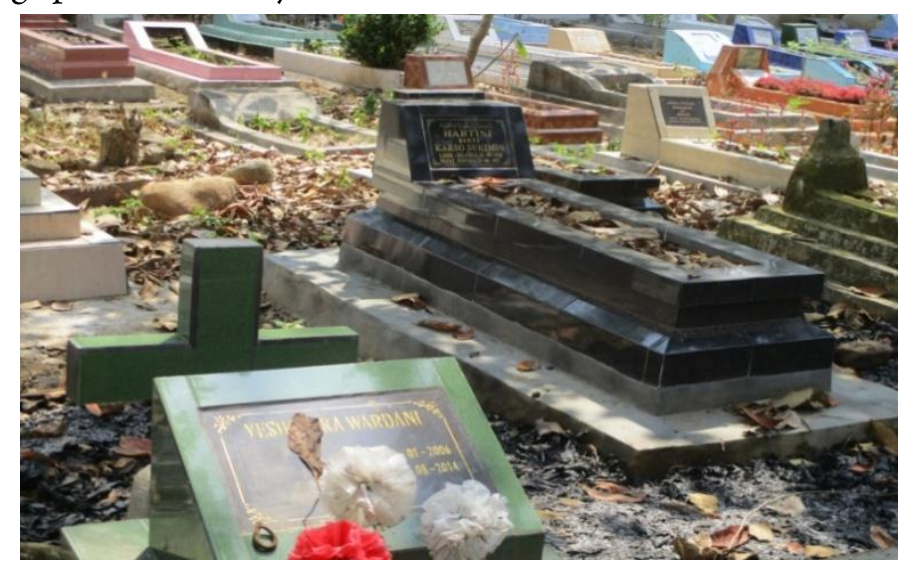

Figure 1. Perintis Cemetery Complex of Hanura Village

The same treatment also appears in the application of citizens' rights and obligations. In the village of Hanura, mutual assistance activities to help residents who are either celebrated or affected by disasters are carried out by all residents without being limited by differences in beliefs. This similar treatment is felt by all members of the village community both majority and minority. The minority does not feel intimidated by the majority group, even feels secured. This refers to the testimony of two Protestant and Catholic Christian religious leaders that the existence of a majority of Muslims in the village of Hanura is not a threat but as a partner and part of the brotherhood of the same countrymen and fellow citizens. ${ }^{41}$ On the other hand, the Muslim community in the village of Hanura did not

40 "Location of the Cemetery in Hanura Village," Observation (Hanura Village, August 16, 2018).

${ }^{41}$ Beta $\underline{\text { Herlin }}$, Pastor of Beith Tefilah Protestan Church, Interviview ${ }_{\perp} \underline{6}$ S September

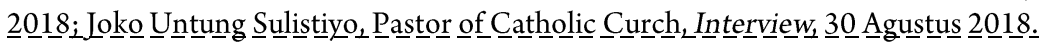


act proud, but is very tolerant and protective of the non-Muslim community. ${ }^{42}$ Such conditions ultimately form majority-minority relations in equal relations without discrimination. ${ }^{43}$

\section{Coherence of community social activities}

Social coherence in an area can be used as an indicator of harmonious relations between elements of society in the area. In this context, the Hanura village community can be considered to be a miniature of the archipelago consisting of various tribes in the country. The population of the Hanura village in 2017 amounted to 6641 inhabitants consisting of $10 \%$ Lampung tribe, $60 \%$ Javanese tribe, 10\% Palembang tribe, $15 \%$ Sundanese tribe, the rest was mixed with other tribes in the country. ${ }^{44}$ Although at the beginning the formation of the village of Hanura was a transmigration village of the Indonesian Army, in its development, the village of Hanura grew into a multi-ethnic, multi-work and multi-religious village.

In addition to ethnic diversity, Hanura villagers also have quite a variety of jobs. Hanura villagers who work as PNS-TNI-Polri are recorded at $40 \%$, traders $20 \%$, laborers / farmers / fishermen $20 \%$, the rest are mixed professions. ${ }^{45}$ The diversity of the professions of the Hanura village community reflects a social community of modern society, namely the existence of social differentiation that works and functions according to their expertise for the welfare of society. Differences in the profession do not form the dividing line of social relations between citizens: On the contrary, it shows a fairly high level of social coherence. The Muslims there do not separate themselves from other communities. Likewise, non-Muslim communities are able to live side by side with the Muslim communities. In short, relationships among fellow citizens appear to be very fluid in various daily activities. Commenting on this phenomenon, Reverend Joko Untung Sulistiyo stated: "A person's perfect faith in his religion will bring him into good social interaction with others. It is precisely the attitude of intolerance

${ }^{42}$ Hasri, Chairman of MUI Teluk Pandan District, Interview, 13 September 2018.

${ }^{43}$ Fajar Riza Ul Haq, “Sambutan Ma'arif Institut," in Fikih Kebinekaan, ed.

Wawan Gunawan Abdul Wahid, Muhammad Abdullah Darraz, and Ahmad Fuad Fanani (Bandung: Ma'arif Institut dan Mizan, 2015): 8.

${ }^{44}$ Yudi Apriyanto, Secretary of Hanura Village, Interview, 16 Agustus 2018.

${ }^{45}$ Ibid. 
and unwillingness to mingle usually occurs with abangans (sincretic religion). ${ }^{46}$

Similar social coherence is also evident among village government officials. Although employees who work at the Hanura Village Hall office have different religions, they are able to establish good relations and work together hand in hand in providing the best service to all citizens. ${ }^{47}$ The coherence of the Hanura village community become more apparent when the community hold the anniversary of the village of Hanura, which falls on every September 17th. To make the series of events success, all members of the community work together hand in hand and take part in all fields of activity, whether art, sports or social activities. In addition, as explained by the chairman of the MUI kec. Teluk Pandan, the village's birthday celebration is also filled with prayer activities with all religious adherents who are led by each religious figure, usually at the grave pilgrimage in the village cemetery complex. ${ }^{48}$

\section{Religious tolerance}

Hanura villagers live in harmony and peace. Until now there is no data that shows the conflict between them despite having different ethnic and religious backgrounds. Religious harmony between them is well preserved. It shows that they have a high tolerance level. The tolerant attitude of the Hanura villagers has been maintained up to now because they realize that religion always teaches harmony and peace in life. Likewise religion teaches that all human beings are God's creatures. ${ }^{49}$

The tolerant attitude of the people in the village of Hanura is reflected in various social activities and community traditions that have been passed on for generations. As seen in the takziyah and feast ceremony of the deceased. The takziyah program for the dead was attended by various groups of villagers. ${ }^{50}$ Religious differences do not prevent them from helping others and expressing their condolences. Despite their different religions, they still maintain social harmony and harmony. As for religious matters, they still maintain their personal identities according to the teachings of their respective religions. Even the freedom of the community to practice

\footnotetext{
${ }^{46}$ Sulistiyo, Martinus Catholic Church.

${ }^{47}$ Yudi Apriyanto, Interview.

${ }^{48}$ Hasri, Chairman of MUI Teluk Pandan District.

${ }^{49}$ Ibid.

${ }^{50}$ Ibid.
} 
religious teachings not only gets security guarantees from village government officials, but is also supported by all villagers. This can be seen in the implementation of religious holidays both Islam, Christianity, Catholicism and others. For example, when Muslims hold the Iedul Fitri and Iedul Adha Holidays, Christian youths help organize and maintain vehicle parking locations at the Bait al-Iqrar Mosque. Vice versa when Christians in the village of Hanura carry out Christmas celebrations, young Muslims do security guard and vehicle parking areas in churches that conduct worship services. ${ }^{51}$

Tolerance among religious people in the village of Hanura continues to be fostered and maintained by both the community and the village government of Hanura. The Hanura village government supports every effort to instill tolerance values for the Hanura village community, including religious social activities aimed at strengthening the values of pluralism and tolerance,

According to Abdul Jamil, there are several potential factors for realizing community harmony, including: 1) Local wisdom; 2) Religious teachings and the role of religious leaders as a unifying symbol; 3) Government political support to achieve harmony; 4) Interdependence among residents in efforts to meet the needs of daily life; 5) The existence of multicultural dialogue forums across religions, cultures, ethnicities, through various media. ${ }^{52}$

Referring to the five factors above, the Hanura village community has all the factors that support the realization of community harmony. First, the people of Hanura village have quite good local wisdom. The local wisdom of the Hanura village community is reflected in the policies of the village administration in protecting and serving the community. Second, the religious teachings adopted by each citizen are carried out in accordance with their respective beliefs with the principle of mutual respect for each other. Likewise, religious leaders in the village of Hanura played a big role in creating community harmony. They attended community events and joined in with the wider community in various community and village activities. In short, togetherness and unity between religious communities are clearly reflected in daily life of the community. Third, the Hanura village

\footnotetext{
${ }^{51}$ Yudi Apriyanto, Interview.

52 Abdul Jamil, Potret Kerukunan Umat Beragama Di Provinsi Jawa Timur (Jakarta: Puslitbang Kemenag RI, 2011).
} 
government provides support for the harmony of religious life in the village. Fourth, Hanura villagers have a high dependency on one another. This is manifested in daily social life as seen in mutual cooperation activities and celebrations of religious holidays. Fifth, villagers often hold interfaith dialogue seminars or forums on tolerance, religious harmony and multicultural culture.

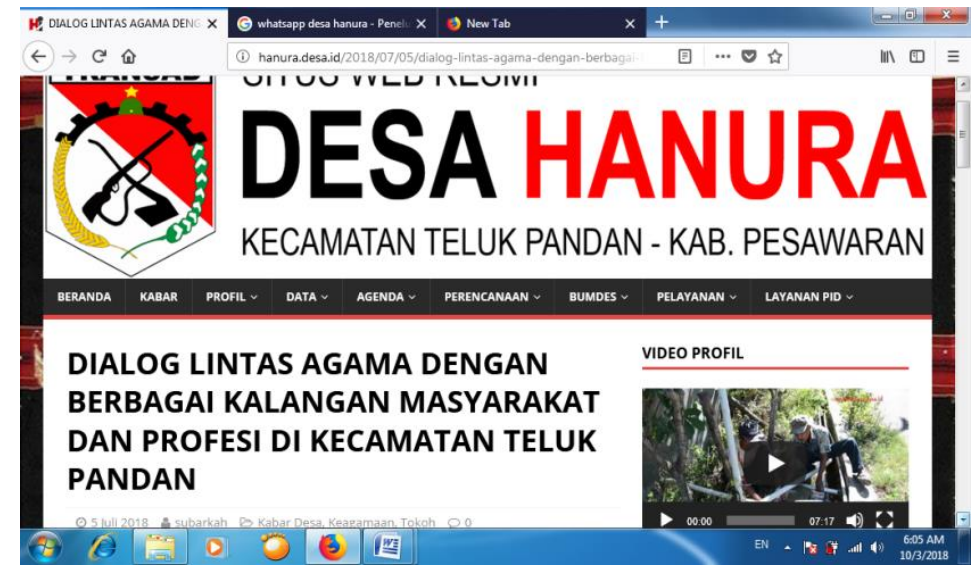

Figure.2. An interfaith dialog session in Hanura Village.

From the three indicators of pluralism above, it can be said that the Hanura villagers implement the values of pluralism in their daily lives. They recognize the existence of equal rights between them, including the right to choose a religion and worship according to the teachings of their respective religions. In all activities of daily life, Hanura villagers also show social coherence that is good enough to create a harmonious life between them. The spirit of tolerance between them is also quite good, which is shown by mutual respect and help each other to realize a harmonious life.

\section{Implementation of Pluralism Values in Hanura Village and Its Relevance to the Medina Charter}

As described above, Hanura villagers have implemented pluralism values well. Referring to the data obtained, the implementation of pluralism in the Hanura village community can be measured in three parameters: equality of rights and obligations among citizens, coherence of social activities, and tolerance of religious life. In the following description, the relevance of the three indicators to the values of pluralism in the Medina Charter will be discussed. 


\section{Equality of rights and obligations.}

Equal rights and obligations are part of human rights. This is stated in the UN Human Rights manifesto in articles 1,2, 3 and 7. These equality rights vary, including; equality before the law, equality before the law (court). Civil liberties rights also vary, including; the right to individual freedom, the right to property, the right of authority in the home (residence), the right to foster family, the right to freedom of creed and worship, the right of freedom of opinion, the right of teaching, the right to life, and other rights.

In the context of the Indonesian state, equality of rights and obligations for every citizen is regulated in the 1945 constitution. This is also in line with what is summarized in the points of the Medina Charter in which the rights and obligations between Muslims and Jews were regulated equally. In Islamic doctrine, the principle of absolute equality must be applied between human beings, regardless of skin color, ethnicity and religion.

The basis of equality in Islamic Sharia has strong roots to the fact that all humans come from a man and a woman, namely: Adam and Eve. Then Allah made them nations and tribes to get to know and cooperate with each other. They should not be proud of their offspring, because there is no difference between nations on the basis of their ancestral privileges and selfesteem. Al-Qur'an: al-Hujurat: 13 confirms that all human beings are equal; the only thing that distinguishes them is the noble nature they have and the good deeds based on piety. Among the examples of the application of the principle of equality in Islam one example can be understood from a story of Abdullah bin Amr bin Ash, ruler of Egypt at the time of Caliph Umar bin Khattab. Abdullah bin Amr bin Ash was rumored to have hit an Egyptian Coptic (orthodox Christian) follower because he won a horse race. The Coptic follower complained to the Caliph Umar, then the Caliph sent messengers to Amr bin Ash and his son to come to the Caliph. When the two of them came to face, the Caliph Umar brought in the coptic who had complained earlier, then said to him: "Is this the person who hit you earlier? He answered: "Yes", Umar said: "Beat him". So the man hit Abdullah bin Amr until he was satisfied. Then Umar said to him: "Add more noble children", then Umar turned to Amr bin Ash and said to him: "O Amr since when did you enslaved humans, even though they were born by their 
mothers in a free state ?". This event is one proof that humans in Islam have the same position, such as comb teeth, parallel and help each other. ${ }^{53}$

In Islamic law, the concept of equality includes two rights: equality before the law, and equality before the law (court). In the Medina Charter, precisely in the second point, there is the sentence 'innahum ummatun wāhidah min dūni an-nas' which means "they are actually one people but different from other communities. ${ }^{54}$ The sentence implicitly suggests that all residents of Medina, both Muslim and non-Muslim, Ansari and Muhajirin are all one people, who have the same rights and obligations, and must be treated equally in matters of the state, law, economy, politics and social.

In the context of the village of Hanura, this equality is practiced in the form of the unification of burial sites of different religious communities, ${ }^{55}$ although, in Islamic Law, the mixing of graves of different religions is still a matter of debate. As revealed by Ibn Hazm in al-Muhalla, some fuqaha (jurists) forbid the burial of Muslims with non-Muslims side by side and should not be a dead Muslim buried in a non-Muslim cemetery, and vice versa. However, some other fuqaha allow to bury Muslims in nonMuslim cemeteries in an emergency, because there is no other land except the public burial. ${ }^{56}$

The fuqaha who allow the burial method reason their argument with the Surah an-Najm: 39 that a person will not get a reply (in his grave) except what he has done. In other words, a Muslim is not affected by his burial place, but his deeds during his lifetime. This argument is reinforced by the words of the Prophet's companion, Salman al-Farisi, that the land will not be able to glorify someone but the deeds that can glorify it. The words of the Companions of the Prophet SAW were issued by Imam Malik bin Anas in al-Muwaththa, with no. Hadith 2842 and Abu Nuaim al-Asfahani in the

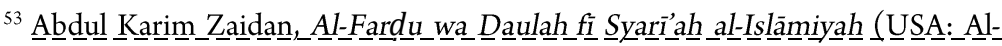

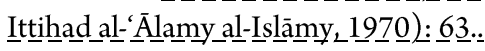

${ }^{54}$ Muhammad Hamidullah, Majmū'ah al-Watsāiq al-Siyāsiyah Li al-'Ahdi alNabawi Wa al-Khilāfah al-Rāsyidah (Beirut: Dār Nafāis, 1985).

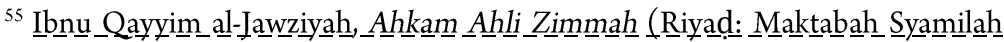
2.11, t.t.t. 2 . 69 :

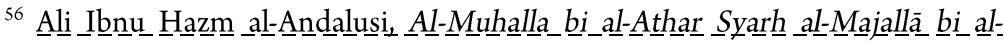

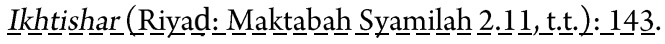


book Hilyat al-Awliyā. ${ }^{57}$ Furthermore, although in traditions that have taken root in Indonesia the tombs of Muslims from non-Muslims are separated Muslim tombs are specialized in one place or block, so that they are not mixed with the tombs of other faiths - but in Hanura village, such traditions do not apply; the thing where people unite and mix the tombs of all religious communities in the same cemetery complex.

According to Baidhawy there are several main characteristics of a society that has diversity. ${ }^{58}$ First, the society has an open attitude to accommodate all political interests of various elements of society. Secondly, the community has fully implemented a cultural management system that accommodates all existing cultural entities. Third, the society not only recognizes the existence of diverse and different cultures, but also presupposes the willingness and sincerity to respect those cultures without sacrificing loyalty to their own cultural identity. In this way it can be expected that cultures can learn from one to another to coexist and work together.

It is difficult to argue that equal treatment of citizens of various religions and ethnicities is the main foundation for upholding justice in the life of society and the state. According to the philosopher Emanuel Evinas, in a society, justice is only called justice when there is no difference between those who are close to those who are far away and vice versa. ${ }^{59}$ In line with that, Gamal al-Banna asserted that social diversity is sunatullah, while monotheism is only related to the nature of God, not the realm of beings. Therefore, it is forbidden to force diversity into a uniform because it will cause shirk (betraying God) ${ }^{60}$ In similar context, Syafi'i Ma'arif states how difficult it is to realize justice in differences, but it would be glorious if it could be realized. Indonesia's diversity, as a reality, requires a fundamental

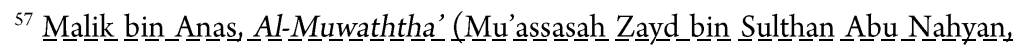

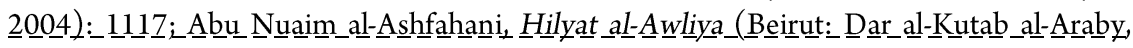
1405):205:

${ }^{58}$ Zakakizuddin_

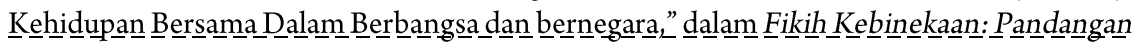

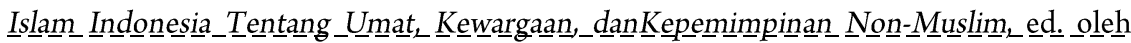
Wawan GUnawawan A

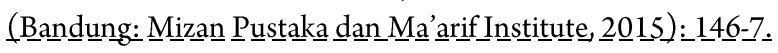

${ }^{59}$ Souleymane Bachir Diagne, "Religion and The Challenge of Spirituality

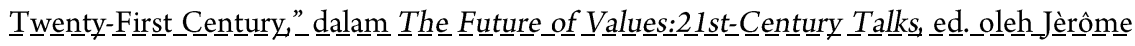

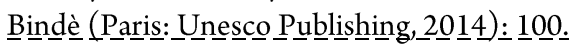

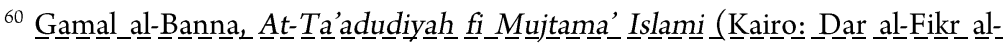
Islami, t.t.t.): 4 . 
paradigm shift, from an attitude to monopolize the truth to an attitude to share. Here all elements of the nation must be seen in a whole humanity perspective. ${ }^{61}$

In the political life of the state, Islam has outlined the principles of behavior for Muslim and non-Muslim citizens. The Prophet himself had made the will that non-Muslim citizens be treated the same as Muslims. The fuqaha had agreed that the law protecting zimmis (non-Muslim citizens) was obligatory and hurting them was haram (strongly forbidden). Whoever persecuted them, even with one bad word or vilified someone's good name, or any form of persecution, or helped to hurt him, then he is considered having wasted the mandate of Allah and His Messenger. It is exemplified by the fuqaha that when kafir zimmi who are under in charge of Muslim are attacked by kafir harbiy, then it is obliged upon the Muslims to fight them with all weapons and war equipment, to keep the responsibility of Allah and His Messenger.

\section{The coherence of social activities}

Social coherence is an indicator of harmony in the relationship between elements in the society. In this context, Hanura Village Coherence can be used as a concrete example. In villages where the population consists of multi-ethnic, multi-professional, multi-religious and religious beliefs, differences between citizens do not constitute a dividing line for social relations between people: On the contrary, it shows a fairly high level of social coherence. Muslims in this village do not separate themselves from other communities. Likewise for non-Muslim communities, they live side by side peacefully with Muslim communities without any social barriers.

The diversity of the professions of the Hanura village community also reflects a social community of modern society, namely the existence of social differentiation that works and functions according to their expertise for the welfare of society. The same thing can also be found among village government officials. Although employees who work at the village government office have different religions, they are able to establish good relations and work together hand in hand in providing the best service to all citizens. ${ }^{62}$ The coherence of the Hanura village community became more apparent when the community held the anniversary of the village of Hanura,

${ }^{61}$ Ma'arif, Islam dalam Bingkai Keindonesiaan dan Kemanusiaan: Sebuah Refleksi Sejarah: 300.

${ }^{62}$ Yudi Apriyanto, Interview. 
which falls on every September 17th. To make the series of events a success, all members of the community work hand in hand together and take part in all fields of activity, whether art, sports or social activities. In fact, as explained by the chairman of the MUI Teluk Pandan district, the village's birthday celebration is also filled with prayer activities with all religious adherents who are led by each religious figure, usually at the grave pilgrimage in the village cemetery complex. ${ }^{63}$

The above phenomenon is quite similar to the social situation at the time the Prophet compiled the points of agreement contained in the Medina Charter. There were thirteen groups who bound themselves in the Medina charter, namely: Muhajirin Muslims from the Quraysh of the Mecca; Muslims from Yathrib / Medina; Jews from the Children of Auf; Jews from the Children of Sa'idah; Jews from Bani al-Hars; Bani Jusyam; Jewish Bani al-Najjar; Jewish Bani 'Amr ibn Auf; Banu al-Nabit; Bani al-Aus; Jewish Children of Tha'labah; Jafnah Bani Tha'labah tribe, and Bani Syuthaybah. The tribal names mentioned in the Medina Charter and a number of customs that prevail in the environment of the tribes are proof that the Prophet Muhammad was very realistic. Here the Prophet acknowledged the existence and influence of the tribes and allowed customary deeds to continue. ${ }^{64}$

According to Yasin Ghadban, the first inhabitants of the city of Medina, formerly called Yathrib, were Arabs from the Amaliq tribe of Banu Haf. Then came the Arab Jews from Yemen, followed by other tribes, including Muslims who came from the City of Mecca. According to Sofiyurrahman's finding, the agreements made by the Messenger of Allah in the form of the Medina Charter have in fact often been applied by various groups and tribes from both Arabs and Jews. ${ }^{65}$ From the points of the Medina charter it illustrates the coherence of the social activities of the people in it, both Muslim and non-Muslim, who blend in government and economic activities. Hasan Khalid explained that the mingling of the Jewish community with the Arab tribes in Medina caused them to adopt the characteristics of the Madinah Arab community and vice versa. It is through such a mechanism that the process of interaction / muāmalah naturally

\footnotetext{
${ }^{63}$ Hasri, Chairman of MUI Teluk Pandan District.

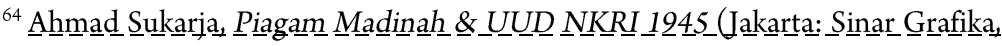
2012):99.

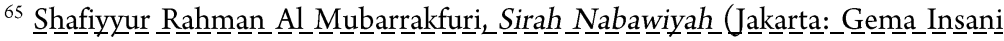
Pers, 2013): 14 148-9.
} 
occurs; Even the Jews who were mostly traders eventually became a part of the economic movement in Medina society. ${ }^{66}$

Relationship with the Medina Charter because the facts that occurred in Medina at that time and those in Indonesia had a similarity namely the reality of pluralism that exists at the community level. Other facts also show that theologically and philosophically the Medina Charter and the Pancasila clearly illustrate the very essential relationship between hablum minnallāh (relationship with God) and hablum minannās (relations between humans). Through a combination of the relationships, piety created by vertical relationships will have a direct impact on social piety manifested in horizontal relationships. ${ }^{67}$

\section{Religious tolerance}

Religious tolerance that occurred in the village of Hanura, can actually be seen as a reflection of Islamic values summarized in the Medina Charter. The practice of religious tolerance in the village of Hanura has been carried out since the founding of the village and has been maintained until now. The tolerance in the village is reflected in various traditions and activities, such as ta'ziyah events and the obstruction of the deceased which is attended by various groups of villagers. ${ }^{68}$

This attitude of tolerance is based on the awareness that human beings are all creatures of God - which, in Nurkhalis' terms, human being is one and has one God; Helping others without seeing differences in religion, ethnicity and race is part of religious teachings. Allah SWT himself in the Sura al-Kafirun: verse 6 asserts: "For you your religion and for me my religion", which means that the practice of religion is the right of privacy of religious followers without the intervention of other parties.

As the celestial religion carried by the last Apostle, Islam does not ignore the reality that occurs in society. In the eyes of Islam, the diversity of nations, cultures and religions in society is a necessity as a provision of God. The affirmation was followed up by the Prophet SAW by giving freedom to each religious group in Medina to practice the teachings of their religion as well as possible. The Medina Charter is basically a binding agreement

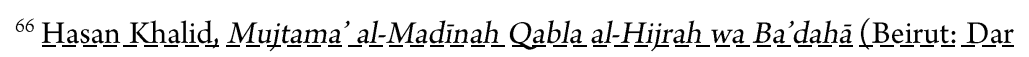

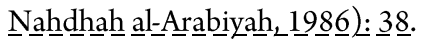

67 Zakiyuddin Baidhawi, "Piagam Madinah dan Pancasila: Prinsip-Prinsip Kehidupan Bersama Dalam Berbangsa dan bernegara.": 127-159.

${ }^{68}$ Hasri, Chairman of MUI Teluk Pandan District. 
between Muslims and followers of other religions in Medina. As proof of this practice, Rasulullah SAW married Maria Qibtiyah, a Coptic woman (Orthodox Christian sect) from Egypt, who gave her a son named Ibrahim. Likewise the Prophet Muhammad married Shofiyyah bint Huyay, a Jewish woman, the daughter of a Jewish leader of Khoibar-Medina, Huyay bin Ahthob. ${ }^{69}$

Turning to the core issue of this description, the attitude of tolerance among religious people that occurs in the village of Hanura, in the national perspective, can also be interpreted as one of the first principles of the practice of Pancasila, the basis of the philosophy of the Republic of Indonesia. The first precepts are in line with the values of the Medina charter, namely the attitude of respecting adherents of other religions. The first precept in the Pancasila itself, according to Baidhawi, ${ }^{70}$ contains several main points namely: First, the norm of internal freedom; Every citizen on this motherland has the right to adhere to a religion in accordance with their respective beliefs. Islam itself gives every individual the right and freedom to choose whether he will believe (become Muslim) or kufr (choose another religion). Second, the norm of external freedom; Every citizen has the freedom to practice his religion or belief, whether in the form of teachings, practices, worship and obedience, whether individually, in congregation, or in community with other adherents, in the private or public sphere. Third, the norm without coercion; Every citizen must not be subject to coercion, pressure, intimidation, repression that will interfere with or hinder his freedom to own or adhere to a religion or belief based on their respective choices. Fourth, the norm of fair treatment; The state is obliged to respect and ensure that all individuals in their jurisdiction are free to follow any religion and belief without limitation of race, color, sex, language, political views, national origin, wealth, birth status whatsoever. Fifth, the norm of parental/guardian rights; The state guarantees that parents/legal guardians have the legal right to ensure religious and moral education for their children according to their own beliefs, while providing protection for the rights of every child to choose any religion or belief according to their own choice.

Last but not least, there are 5 (five) things that one should aware of as they are potential to disturb harmony and cause intolerance, namely: 1)

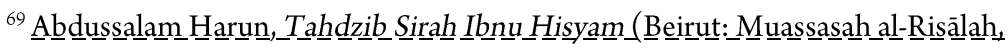
1985): $43 \underline{3}$

70 Zakiyuddin Baidhawi, "Piagam Madinah dan Pancasila: Prinsip-Prinsip Kehidupan Bersama Dalam Berbangsa dan bernegara.": 150-3
} 
Construction and use of houses of worship that are not in accordance with regulations; 2) Unhealthy political competition and misuse of religious symbols for the benefit of groups; 3) Differences in understanding and practice of religious teaching that are not in accordance with the mainstream group; 4) Socio-economic inequality; 5) The development of a global culture that is not in harmony with local wisdom and religious teachings. The five things above must be watched out by Hanura villagers, including all villages in the archipelago, because if the issue spreads, the peace and harmony of life of the people who have been running well will easily collapse and turn into prolonged social conflicts.

\section{E. Conclusion}

Based on what has been widely explained previously, it can be concluded that the life of Hanura villagers is a real portrait of the implementation of pluralism values of the Medina Charter and is in accordance with Islamic teaching. This is indicated by three indicators, namely: the existence of equal rights and obligations between citizens, the realization of the coherence of social activities, and the development of inclusive attitude of tolerance in religion. Thus, the life of the Hanura villager can be used as a model for other regions in applying the values of pluralism in Indonesia. [.]

\section{Acknowledgment}

Deep appreciation to the Office for Research and Community Service (LPPM) of State Islamic University (UIN) Raden Intan Lampung for the research grants so that this research can be carried out.

\section{References}

Achmad. "Pluralisme Dalam Problema." Jurnal Sosial Humaniora Vol. 7, no. 2 (2014).

Andalusi, Ali Ibnu Hazm al-. Al-Muhalla Bi al-Athar Syarh al-Majallā Bi alIkhtishar. Riyad: Maktabah Syamilah 2.11, n.d.

Armayanto, Harda. "Problem Pluralisme Agama." Jurnal Tsaqafah Vol. 10, no. 2 (2014). 
Ashfahani, Abu Nuaim al-. Hilyat Al-Awliya. Beirut: Dar al-Kutab al-Araby, 1405.

Azra, Azyumardi. "Bali and Southeast Asia Islam: Debunking The Mith." In After Bali: The Threat of Terrorism in Southeast Asia, edited by Kumar Ramakishna and See Seng Tan. Singappre: World Scientific Publishing Co. Pte. Ltd., 2003.

Bagus, Loren. Kamus Filsafat. Jakarta: PT. Gramedia Pustaka Utama, 2000.

Baidhawi, Zakiyuddin. "Piagam Madinah Dan Pancasila: Prinsip-Prinsip Kehidupan Bersama Dalam Berbangsa Dan Bernegara.” In Fikih Kebinekaan: Pandangan Islam Indonesia Tentang Umat, Kewargaan, Dan Kepemimpinan Non-Muslim, edited by Wawan GUnawan Abd. Wahid, Muhammad Abdullah Darraz, and Ahmad Fuad Fanani. Bandung: Mizan Pustaka dan Ma’arif Institute, 2015.

Banna, Gamal al-. At-Ta’adudiyah Fi Mujtama' Islami. Kairo: Dar al-Fikr alIslami, n.d.

Diagne, Souleymane Bachir. "Religion and The Challenge of Spirituality in The Twenty-First Century." In The Future of Values:21st-Century Talks, edited by Jèrôme Bindè. Paris: Unesco Publishing, 2014.

Hamidullah, Muhammad. Majmū'ah al-Watsāiq al-Siyāsiyah Li al-'Ahdi alNabawi Wa al-Khilāfah al-Rāsyidah. Beirut: Dār Nafāis, 1985.

Hanik, Umi. "Pluralisme Agama Di Indonesia." Tribakti: Jurnal Pemikiran Keislaman Vol. 25, no. 1 (2014).

Haq, Fajar Riza Ul. “Sambutan Ma’arif Institut.” In Fikih Kebinekaan, edited by Wawan Gunawan Abdul Wahid, Muhammad Abdullah Darraz, and Ahmad Fuad Fanani. Bandung: Ma'arif Institut dan Mizan, 2015.

Harun, Abdussalam. Tahdzib Sirah Ibnu Hisyam. Beirut: Muassasah alRisālah, 1985.

Hasri. Interview, September 13, 2018.

Herlin, Beta. Interview, September 6, 2018.

Hick, John. An Interpretation of Religion: Human Respons to the Transcendent. London: Macmillan, 1989.

- - - Tuhan Punya Banyak Nama. Translated by Amin Ma'ruf. Cet. I. Yogyakarta: Interfidei, 2006.

Hornby, A.S. Oxford Advanced Learner's Dictionary of Corrent English. Cet. XI. London: Oxford University Press, 1983. 
Husaini, Adian. Wajah Peradaban Barat. Jakarta: Gema Insani, 2005.

Jamil, Abdul. Potret Kerukunan Umat Beragama Di Provinsi Jawa Timur. Jakarta: Puslitbang Kemenag RI, 2011.

Jawziyah, Ibnu Qayyim al-. Ahkam Ahli Zimmah. Riyaḍ: Maktabah Syamilah 2.11, n.d.

Khaerurrozikin, Ahmad. "Problem Sosiologis Pluralisme Agama Di Indonesia." Jurnal Kalimah Vol. 13, no. 1 (2015).

Khalid, Hasan. Mujtama' al-Madinah Qabla al-Hijrah Wa Ba'dahā. Beirut: Dar Nahdhah al-Arabiyah, 1986.

Legenhausen, M. Pluralitas Dan Pluralisme Agama. Jakarta: Shadra Press, 2010.

"Location of the Cemetery in Hanura Village." Observation. Hanura Village, August 16, 2018.

Lumintang, Stevri Indra. Teologi Abu-Abu (Pluralisme Iman). Cet. I. Malang: YPPII, 2002.

Ma'arif, Ahmad Syafi'i. Islam Dalam Bingkai Keindonesiaan Dan Kemanusiaan: Sebuah Refleksi Sejarah. Bandung: Mizan Bekerjasama dengan Ma'arif Institut, 2009.

Madjid, Nurcholish. Kebebasan Beragama Dan Pluralisme Dalam Islam. Jakarta: Gramedia Pustaka Utama, 2001.

- - Masyarakat Religius. Jakarta: Paramadina, 2000.

-_- Tiga Agama Satu Tuhan. Bandung: Mizan, 1999.

Malik bin Anas. Al-Muwaththa'. Mu'assasah Zayd bin Sulthan Abu Nahyan, 2004.

Misrawi, Zuhairi. Al-Qur'an Kitab Toleransi: Inklusivisme, Pluralisme, Dan Multikulturalisme. Cet. I. Jakarta: Fitrah, 2007.

Moko, Catur Widiat. "Pluralisme Agama Menurut Nurcholis Madjid (19392005) Dalam Konteks Keindonesiaan.” Medina-Te Vol. 16, no. 1 (2017).

Mubarrakfuri, Shafiyyur Rahman Al. Sirah Nabawiyah. Jakarta: Gema Insani Pers, 2013.

Munawar-Rachman, Budi. “Perspektif Global Islam Dan Pluralisme.” Ilmu Ushuluddin Volume 1, no. 3 (2012).

Nasution, Harun. "Islam Dan Sistem Pemerintahan Dalam Perkembangan Sejarah.” Nuansa, Jakarta: Desember 1984. 
Nebukadnezar, Faiq. "Pandangan Al-Qur'an Terhadap Pluralisme Agama: Telaah Kritis Ayat-Ayat Teologis Dalam Al-Qur'an'” Tesis, IAIN Surakarta, 2018.

“Oxford Advanced Learner's Dictionary.” London: Oxford University Press, 1989.

Youtube. "Profil Desa Hanura." Accessed June 7, 2019. https://www.youtube.com/watch?v=DVgMH0Vk9W4.

Situs Web Resmi Desa Hanura. "Profil Desa Hanura." Accessed July 19, 2019. http://hanura.desa.id/profil/.

Rahman, M. Syaiful. “Islam Dan Pluralisme.” Fikrah Vol. 2, no. 1 (n.d.): 2014.

Rakhmat, Jalaluddin. Islam Dan Pluralisme: Akhlak Qur'an Menyikapi Perbedaan. Cet. II. Jakarta: Serambi, 2006.

Rumadi. Damai Bersama Gus Dur. Jakarta: Kompas Media Nusantara, 2010.

Schuon, Frithjof. The Transcendent Unity of Religions. n.p.: Quest Book Theosophical Publishing House, 1984.

Sukarja, Ahmad. Piagam Madinah \& UUD NKRI 1945. Jakarta: Sinar Grafika, 2012.

Sulistiyo, Joko Untung. Interview, August 30, 2018.

Sumbulah, Umi, and Nurjannah. Pluralisme Agama: Makna Dan Lokalitas Pola Kerukunan Antarumat Beragama. Malang: UIN-Maliki Press, 2013.

The Encyclopedia of Religion. New York: Simon \& Schuster Macmillan, 1995.

Thoha, Anis Malik. "Konsep World Theology Dan Global Theology Eksposisi Doktrin Pluralisme Agama, Smit Dan Hick.” ISLAMIA Vol. 1, no. 4 (2005).

- - - Tren Pluralisme Agama. Cet. I. Jakarta: Perspektif, 2005.

Wahid, Abdurrahman. Prisma Pemikiran Gus Dur. Yogyakarta: LKiS, 2010.

Yudi Apriyanto. Interview, August 16, 2018.

Zaidan, Abdul Karim. Al-Farḍu Wa Daulah Fī Syarīah al-Islāmiyah. USA: Al-Ittihad al-'Ālamy al-Islāmy, 1970. 